\title{
M. Michael Cohen, Jr.: Author, diagnostician, geneticist, teacher, mentor, syndrome scholar extraordinaire (1937-2018)
}

When it comes to observation, chance favors the prepared mind.

\section{1 | INTRODUCTION}

The remarkable contributions of Dr Michael Cohen to the field of medical genetics encompass many areas of the discipline. His scholarship is emblematic of the famous aphorism above attributed to Louis Pasteur. Among his noteworthy achievements was his particular role in the recognition and delineation of syndromes involving multiple congenital anomalies and intellectual disability: While visiting a Colorado facility for persons with disabilities in the early 1970s, Dr Cohen encountered two siblings with a similar pattern consisting of cognitive disability, distinctive face and digits, and obesity. At the University of Washington soon after, he examined a girl who was presented to him by his colleague, Dr Bryan Hall. Dr Cohen immediately recognized that she had the same condition as the sibs in Colorado. While he labeled this newly recognized syndrome as the "Colorado syndrome," the disorder was later designated as Cohen syndrome (Carey \& Hall, 1978). A gene, VPS13B (or COH1), was subsequently identified to account for most individuals who have Cohen syndrome (Kolehmainen et al., 2003).

The original description of the Weaver syndrome also illustrates this narrative: Drs David Weaver and David Smith had introduced Dr Cohen to a boy with a quite distinctive pattern of features. Soon after he met another individual near the same age who he immediately recognized as having the same condition. Weaver, Graham, Thomas, and Smith (1974) characterized the two patients, and several years later Gibson et al. (2012) identified EZH2 as the gene underlying the syndrome.

Other stories highlight this noteworthy milestone of Michael Cohen's legacy: at the 1978 March of Dimes Birth Defects meeting in San Francisco, he presented two separate papers, one describing the original family with "craniofrontonasal dysplasia" and the other an early description of what came to be known as Proteus syndrome (Cohen, 1979; Cohen \& Hayden, 1979; Wiedemann et al., 1983). The recognition of this "newly recognized hamartomatous syndrome" is of particular note because 10 years later, $\operatorname{Dr}$ Cohen (1989) published his famous account proposing that Joseph Merrick, the so-called "Elephant Man," had Proteus syndrome rather than the conventional view held during most of the 20th century that Mr Merrick had neurofibromatosis.

\section{2 | DIAGNOSTICIAN AND SCHOLAR}

M. Michael Cohen, Jr. was born in Cambridge, Massachusetts on March 28, 1937. After high school he enrolled at University of Michigan in Ann Arbor, majoring in English and later switching to anthropology, a lifelong interest that played a defining role in his career-long focus on bone biology and associated disorders. Dr Cohen then attended Tufts University School of Dental Medicine following the lead of his father who was a dentist, but also an academician (author of 2 books and 75 publications). While at Tufts two important events occurred: he met his future wife, Fay Goodman (married 53 years), and he encountered the book, Syndromes of the Head and Neck by Dr Robert Gorlin, which immediately resonated with his deep interest in syndromes. After completion of dental school, Dr Cohen would join Gorlin, his lifelong mentor, as Dr Gorlin's first genetics fellow at the University of Minnesota. While in Minneapolis he initiated the coursework and thesis prospectus for a PhD in anthropology. Dr Cohen left Minnesota in 1971 to become an Assistant Professor at the University of Washington in three departments: Oral and Maxillofacial Surgery and Orthodontics in the School of Dentistry, and Pediatrics in Medicine. In the next five years he advanced to full Professor on a rapid trajectory, likely related to the prolific publication record that marked his entire career, and was awarded a PhD from the University of Minnesota for his study of cranioskeletal growth in achondroplasia.

During the 10 years at the University of Washington, Dr Cohen developed a close working relationship with Dr David Smith, considered by all as the father of dysmorphology. He also maintained close collaboration with Dr Smith's fellows; Drs Bryan Hall, Kenneth Lyons Jones, John Graham, and Margot Van Allen. During his faculty position at University of Washington, he also worked with a number of other notable figures in teratology and the field of birth defects research, including Drs Bruce Beckwith, Ronald Lemire, and Thomas Shepard. In the 1970s and 1980s, Dr Cohen authored many important papers especially related to two of his favorite topics, holoprosencephaly and craniosynostosis. His interest in the latter theme led to his seminal book, Craniosynostosis: Diagnosis, Evaluation, and Management (1986, second edition, 2000).

At University of Washington, Dr Cohen launched another major aspect of his career and what we refer to as his syndrome scholarship: He was invited by Dr Gorlin to co-author Syndromes of the Head and 


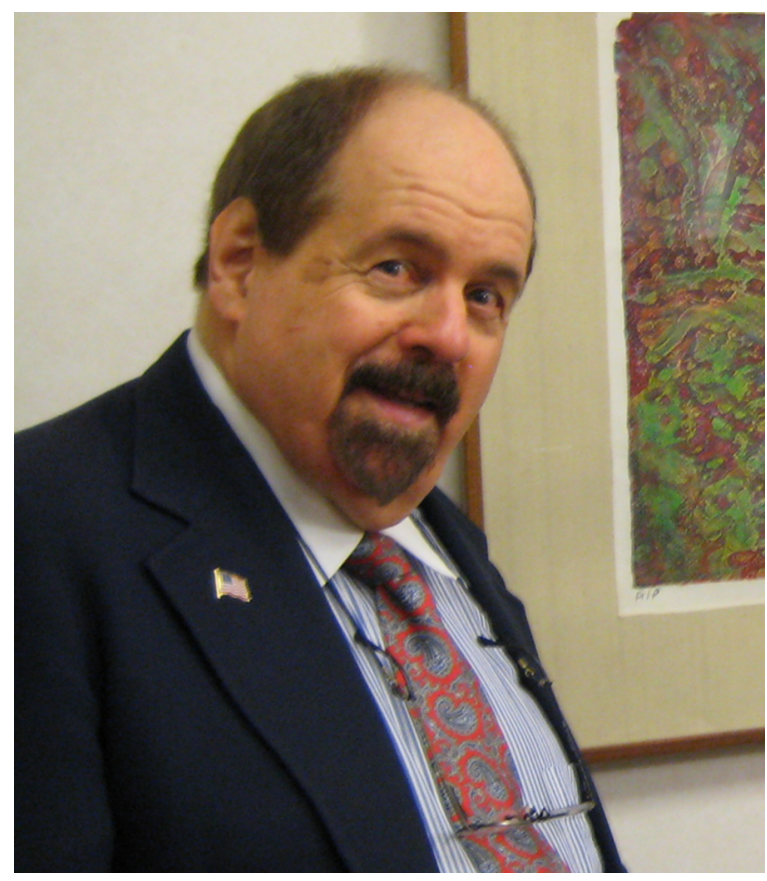

FIGURE 1 M. Michael Cohen, Jr. enjoying one of his deep and life-long loves, modern art [Color figure can be viewed at wileyonlinelibrary.com]

Neck, and he contributed significantly to the second, third, and fourth editions of that classic text. He also authored The Child with Birth Defects followed in 1997 by a second edition (Cohen, 1997). This particular volume deserves special mention. It is a work that eloquently synopsized the principles in the classification of multiple congenital anomalies. The book is likely the most current and definitive work on the epistemology of human patterns of malformation. We still consider it necessary reading for all trainees in medical genetics, and it should be reread by all of those in the field as we approach these challenging times of correlating molecular findings with phenotypes and attempting to make sense of naming syndromes (Carey \& Erickson, 2007).

In 1981, Dr Cohen and his family moved to Halifax, Nova Scotia, where he assumed professorships of dentistry and pediatrics at Dalhousie University. During his tenure at Dalhousie, he served as Chairman of the Oral and Maxillofacial Pathology Department and received appointments in other departments, including Health Service Administration; Sociology and Social Anthropology; and Community Health and Epidemiology, attesting to his remarkably broad knowledge of many disciplines. He maintained his appointment at Dalhousie University until his retirement in 2005 and was a Professor Emeritus until his death in February of 2018.

\section{3 | AUTHOR AND EDITOR}

In addition to the books mentioned above, he also co-authored a number of important works, most notably Overgrowth Syndromes with Drs Neri and Weksberg and Mental Retardation and Malformations of the Central Nervous System with Dr Lemire. His most recent book,
Perspectives on the Face, of which he was quite proud, explores the human face from many viewpoints.

Dr Cohen assumed the role of an Associate Editor of the American Journal of Medical Genetics in 2001 and became the Scientific Reviews Editor in 2010. During these years he composed many seminal reviews for the Journal and two of his papers (Cohen, 2008, 2010) represented the most downloaded articles from the Journal web page in the two years after publication. Recently the Journal compiled the best articles (including the two mentioned above) written by $\mathrm{Dr}$ Cohen and published in AJMG as a Virtual Issue. This is accessible on the AJMG web page (https://onlinelhttps://onlinelibrary.wiley.com/page/journal/ 15524833/homepage/all_virtual_issues.htm)

\section{4 | FESTSCHRIFT}

Another important highlight of his career was the celebration of his contributions with the Festschrift held at the University of Utah in the fall of 2006. A special issue of the American Journal of Medical Genetics comprised articles presented at the Festschrift symposium, and also included several other papers submitted by colleagues and collaborators who were not able to attend the meeting. This particular issue contained 59 articles encompassing various fields of interest to $\mathrm{Dr}$ Cohen including teratology, overgrowth, vascular anomalies, craniofacial malformations, and disorders of bone.

\section{5 | MENTOR AND VISITING PROFESSOR}

Dr Cohen's proudest achievement of recent years was his mentorship of junior clinical investigators around the world. He would meet some

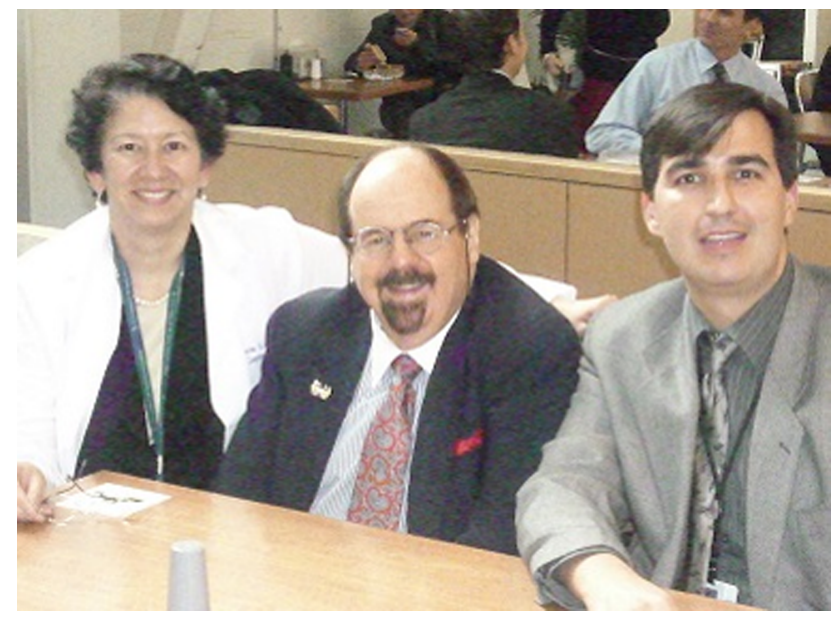

FIGURE 2 In the final years of his career, Dr Cohen loved visiting favorite haunts in his hometowns of Brookline and Boston. From Fenway Park, the Boston University bookstore, and CITGO sign, he trekked out to Revere Beach. He would often meet friends in the café at Mass General Hospital, enjoying the company of a new fellow or international student, holding court about one of his many pet interests (Michael Cohen with Angela Lin and Fabio Nunes, former genetics fellow Harvard Medical School). Above all, he loved the company of his children, grandchildren, extended family, and many friends [Color figure can be viewed at wileyonlinelibrary.com] 
of these younger people at the international meetings he consistently attended in Brazil, Italy, Japan, Denmark, and other parts of the world. From numerous conversations we had with him over the years, his devotion and commitment to these mentees was always at the top of the list of his favorite topics.

\section{6 | OTHER INTERESTS}

Dr Cohen had many talents besides the recognition of syndromes and malformation complexes. He had great curiosity about many subjects and loved learning. Over the years of our friendship, we had the opportunity to explore and discuss with him many of his other interests. During visits, conferences, and long phone calls in between, we had the chance to discuss much besides dysmorphology, such as patient care, biology, environmental science, philosophy, politics, humanities, the state of the world, music, grandchildren, and art. He had a deep interest in modern art (see Figure 1). His lecture on Picasso as viewed by the dysmorphologist was a tour-de-force. He introduced a wide variety of art works into a number of his talks, and a visit to his home was akin to visiting a gallery of modern art. Many people will have recognized his rollicking sense of humor. We know that many, many people have their own favorite story of "Mike."

Dr Cohen will be deeply missed by all of his colleagues and friends in the fields of medical genetics and dysmorphology. As this tribute was written, his legacy and mentorship were being recalled with respect and affection among colleagues and trainees. $\mathrm{He}$ is survived by his wife, Fay and sons; Aaron (New York), Justin (Massachusetts), their spouses, and two grandchildren. They have generously offered to donate many of Dr Cohen's article reprints, books, and CDs of his talks to interested members of the fields; some of his collection will go to the library at Dalhousie University. As mentioned above the most notable of his many publications in AJMG are available free access in a Virtual Issue on the Journal web page.

\section{ORCID}

John C. Carey (DD http://orcid.org/0000-0002-6007-8518

John C. Carey ${ }^{1}$ (D), Raoul C. M. Hennekam², Angela E. Lin ${ }^{3}$, Mason Barr ${ }^{4}$

${ }^{1}$ Division of Medical Genetics, Department of Pediatrics, University of Utah Health, Salt Lake City, Utah

${ }^{2}$ Department of Pediatrics, Academic Medical Center, University of Amsterdam, Amsterdam, The Netherlands ${ }^{3}$ Genetics Unit, , MassGeneral Hospital for Children, Boston, Massachusetts

${ }^{4}$ Teratology Unit, Departments of Pediatrics, Pathology and Obstetrics, University of Michigan, Ann Arbor, Michigan
Correspondence John C. Carey, Division of Medical Genetics, Department of Pediatrics, University of Utah Health, 295 Chipeta Way, Salt Lake City, UT 84108. Email: john.carey@hsc.utah.edu

\section{REFERENCES}

Carey, J. C., \& Erickson, R. P. (2007). Introductory comments: M. Michael Cohen, Jr. Festschrift. American Journal of Medical Genetics Part A, 143A(24), 2851-2852.

Carey, J. C., \& Hall, B. D. (1978). Confirmation of the Cohen syndrome. Journal of Pediatrics, 93(2), 239-244.

Cohen, M. M. Jr. (1979). Craniofrontonasal dysplasia. Birth Defects Original Article Series, 15(5B), 85-89.

Cohen, M. M. Jr. (1988). Further diagnostic thoughts about the Elephant Man. American Journal of Medical Genetics, 29(4), 777-782.

Cohen, M. M. Jr. (2006). Perspectives on the face. New York, NY: Oxford University Press.

Cohen, M. M. Jr., Hall, B. D., Smith, D. W., Graham, C. B., \& Lampert, K. J. (1973). A new syndrome with hypotonia, obesity, mental deficiency and facial, oral, ocular and limb anomalies. The Journal of Pediatrics, 83(2), 280-284.

Cohen, M. M. Jr., \& Hayden, P. W. (1979). A newly recognized hamartomatous syndrome. Birth Defects Original Article Series, 15(5B), 291-296.

Cohen, M. M. Jr. (1997). The child with multiple birth defects (2nd ed.). New York, NY: Oxford University Press.

Cohen, M. M. Jr., Neri, G., \& Weksberg, R. (2002). Overgrowth syndromes. New York, NY: Oxford University Press.

Gibson, W. T., Hood, R. L., Zhan, S. H., Bulman, D. E., Fejes, A. P., Moore, R. ...., Jones, S. J. (2012). Mutations in EZH2 cause Weaver Syndrome. American Journal of Human Genetics, 90, 110-118.

Gorlin, R. J., Pindborg, J. J., \& Cohen, M. M. Jr. (1976). Syndromes of the head and neck (2nd ed.). New York, NY: McGraw Hill.

Kolehmainen, J., Black, G. C. M., Saarinen, A., Chandler, K., ClaytonSmith, J., Träskelin, A.-L., ... Lehesjoki, A.-E. (2003). Cohen syndrome is caused by mutations in a novel gene, $\mathrm{COH} 1$, encoding a transmembrane protein with a presumed role in vesicle-mediated sorting and intracellular protein transport. American Journal of Human Genetics, 72(6), 1359-1369.

Weaver, D. D., Graham, C. B., Thomas, I. T., \& Smith, D. W. (1974). A new overgrowth syndrome with accelerated skeletal maturation, unusual facies, and camptodactyly. The Journal of Pediatrics, 84(4), 547-552.

Wiedemann, H. R., Burgio, G. R., Aldenhoff, P., Kunze, J., Kaufmann, H. J., \& Schirg, E. (1983). The Proteus syndrome: Partial gigantism of the hands and feet, nevi, hemihypertrophy, subcutaneous tumors, macrocephaly or other skull anomalies and possible accelerated growth and visceral affections. European Journal of Pediatrics, 140, 5-12.

\section{AUTHOR BIOGRAPHY}

M. Michael Cohen, Jr., DMD, PhD, died surrounded by his loving family February 11, 2018 in Halifax, Nova Scotia. Dr Cohen had experienced a stroke in 2014 and had physical disabilities subsequent to that event. He contracted the flu in January and pneumonia after that eventually took his life. 